\title{
POKIMAS (PROGRAM KEBUN GIZI MASYARAKAT) DI KOMUNITAS BGBJ, TEMPAT PEMBUANGAN SAMPAH TERPADU (TPST), BANTAR GEBANG, BEKASI, JAWA BARAT
}

\author{
Wardina Humayrah $^{1}$, Megah Stefani ${ }^{2}$, Laila Febrina ${ }^{3}$ \\ ${ }^{1,2}$ Program Studi Gizi, Universitas Sahid Jakarta \\ ${ }^{3}$ Program Studi Teknik Lingkungan, Universitas Sahid Jakarta \\ Email Korespondensi: wardina.humayrah@gmail.com
}

\begin{abstract}
ABSTRAK
Tujuan umum kegiatan Program Kemitraan Masyarakat ini adalah terbentuknya Kebun Gizi Masyarakat Percontohan di Komunitas Kerajaan BGBJ, Bantar Gebang, Bekasi, Jawa Barat sebagai motivator dan penggerak masyarakat sekitar untuk ikut serta dalam POKIMAS di masing-masing rumah tangga. Metode yang dilakukan dalam kegiatan ini menyesuaikan situasi dan kondisi pandemi Covid 19, pelatihan dilakukan secara daring dan modul edukasi diberikan secara lengkap yang akan diberikan kepada semua sasaran sehingga mudah dipelajari mandiri di rumah. Tim PKM akan memberikan TOT (Training of Trainer) secara daring kepada tim inti Komunitas Kerajaan BGBJ dan selanjutnya tim Inti tersebut bertanggung jawab memberikan pelatihan ke 10 peserta sasaran POKIMAS. Hasil dan manfaat yang telah dicapai antara lain: data-data baseline awal tentang kondisi sosio-ekonomi dan pemahaman awal masyarakat sasaran sekitar mitra tentang kebiasaan makan sayur- buah dan kebun; 3 modul terdiri dari rangkaian video-video singkat dan sederhana dalam bentuk Compact Disk (CD) dan link YouTube antara lain: edukasi POKIMAS perwujudan gizi seimbang, pembuatan pupuk takakura, dan pembuatan vertical garden rumahan; serta tindak lanjut pelaksanaan kegiatan POKIMAS di 10 rumah tangga sasaran.
\end{abstract}

Kata kunci : Bantar Gebang; kebun gizi; modul edukasi; pelatihan daring; training of trainer

\begin{abstract}
The general objective of this Community Partnership Program activity is the establishment of a Community Nutrition Garden in the Kingdom of BGBJ, Bantar Gebang, Bekasi, West Java as a motivator and activator for the surrounding community to participate in POKIMAS in each household. The method used in this activity is to adjust the situation and conditions of the Covid 19 pandemic, training was carried out online and a complete educational module is given to all targets so that it is easy to learn independently at home. The USAHID's team will provide online TOT (Training of Trainer) to the core team of the Kingdom of BGBJ Community and then the Core team was responsible for providing training to the 10 POKIMAS target participants. The results and benefits that have been achieved include: initial baseline data on socio-economic conditions and initial understanding of target communities around partners about their eating habits of vegetables and gardens; 3 modules consisting of a series of short and simple videos in the form of a compact disk $(C D)$ and YouTube links, including: education on POKIMAS on the realization of balanced nutrition, making takakura fertilizer, and making a vertical home garden; as well as follow-up on the implementation of POKIMAS activities in 10 target households.
\end{abstract}

Keywords : Bantar Gebang; education modul; nutrition garden; online training; training of trainer 


\section{PENDAHULUAN}

Bantar Gebang adalah salah satu Tempat Pembuangan Sampah (Solid Waste Disposal Site) terbesar di Indonesia yang terletak di Kecamatan Bantar Gebang Kota Bekasi Propinsi Jawa Barat, Indonesia yang telah dioperasikan sejak tahun 1989. TPST Bantar Gebang per harinya menerima $16.000 \mathrm{~m} 3$ dari $20.000 \mathrm{~m} 3 \mathrm{sampah}$ penduduk DKI Jakarta pada tahun 2011. Dan jumlah sampah tersebut semakin meningkat dari tahun ke tahun pada akhir periode tahun 2015 setiap bulan sebanyak 214.972,08 ton/bln. Sampah yang dikirim biasanya berbentuk sampah kering (seperti plastik, kertas dan kardus) dan sampah basah (sayur mayur dan sampah rumah tangga lainnya). Keberadaan sampah di sekitar TPST Bantar Gebang sedikit banyak telah menyatu pada setiap lini kehidupan masyarakat sekitar sehingga secara signifikan berpengaruh kepada kualitas dan biaya kesehatan masyarakat. Penyakit yang umum ditemukan di sana antara lain: infeksi saluran pernafasan atas (ISPA), diare, dan malaria.

Masyarakat sekitar TPST Bantar Gebang adalah masyarakat yang sebagian besar berada pada kelas ekonomi menengah ke bawah. Masyarakat sekitar TPST tersebut juga memiliki tingkat kepedulian yang rendah terhadap pentingnya pendidikan sehingga sulit bangkit dari kemiskinan. Sebagian besar orang tua di daerah TPST Bantar Gebang mempekerjakan anak-anaknya sebagai pengumpul sampah dan mencari uang untuk kehidupan keluarga mereka setelah mereka pulang sekolah. Pendapatan yang tidak tentu dari mata pencaharian sebagai pemulung dan kurangnya keterampilan serta pendidikan mengurangi peluang kesempatan kerja dan perbaikan ekonomi keluarga.

Nama komunitas ini adalah "The Kingdom of BGBJ" atau biasa disebut dengan "Kerajaan Biji-biji Bantar Gebang" merupakan komunitas masyarakat di dalam kawasan Tempat Pembuangan Sampah Akhir (TPSA) Bantar Gebang. Komunitas ini diinisiasi oleh seorang perempuan asli kelahiran Bantar Gebang yang bernama Risa Boenard. Awal kelahiran BGBJ dilator belakangi oleh rasa keprihatinan masa depan masyarakat sekitar (TPSA) yang berada tetap pada lingkaran kemiskinan dengan tingkat ekonomi dan pendidikan rendah dengan mata pencaharian sebagai pemulung atau pengepul sampah. Komunitas ini percaya bahwa anak-anak dan remaja adalah benih untuk masa depan yang positif di TPA.

Berdasarkan, data Komunitas lokal BGBJ menunjukkan bahwa ada sekitar 3000 kepala keluarga yang bertempat tinggal di sekitar Tempat Pengelolaan Sampah Terpadu (TPST) Bantar Gebang, yang berprofesi sebagai pemulung. Anak-anak yang berada di Bantar Gebang umumnya tidak mendapatkan pendidikan layak. Aroma yang menyengat akibat polusi sampah di sekitar TPA, tidak hanya mempengaruhi kesehatan namun juga kondisi mental masyarakat sekitar Bantar Gebang. Banyak di antara warga kurang percaya diri saat harus tampil di lingkungan sosial luar Bantar Gebang karena aroma tak sedap yang menempel di pakaian akibat sampah di sekitar. Mengemban misi untuk mewujudkan mimpi anak-anak di wilayah TPST Bantar Gebang, komunitas lokal ini hadir sebagai wadah edukasi dan salah satu penghubung penduduk Bantar Gebang dengan dunia luar.

Ke depannya, orangtua anak-anak dan remaja sekitar Komunitas Kerajaan BGBJ juga perlu dirangkul untuk ikut serta dalam program edukasi komunitas ini agar dapat sama-sama mendukung peningkatan taraf hidup keluarga masyarakat sekitar. Kondisi rumah-rumah warga sekitar komunitas ini memprihatinkan khususnya yang bermata pencaharian utama sebagai pemulung yang minim akses sanitasi layak dan penghijauan. Penghijauan di sekitar lingkungan warga dapat meminimalisir bau sampah yang 
menyengat.

Di sisi lain, pendidikan para orangtua yang rendah membuat warga sekitar komunitas mengakses sumber pangan rumah tangga apa adanya yang tersedia di warung sekitar. Masyarakat sekitar rentan terhadap penyakit yang timbul akibat sampah dan belum memahami benar manfaat penerapan gizi seimbang bagi anggota keluarga. Konsep gizi seimbang termasuk pelaksanaan perilaku hidup bersih dan sehat serta pemenuhan asupan gizi seimbang seperti konsumsi sayur dan buah untuk daya tahan tubuh menurunkan resiko terjangkit penyakit menular. Masyarakat di sekitar Bantar Gebang memerlukan program yang dapat mendukung pennghijauan sekaligus pemenuhan asupan gizi seimbang seperti konsumsi sayur dan buah untuk meningkatkan taraf kesehatan masyarakat sekitar BGBJ. Oleh karena itu, Program Kebun Gizi Masyarakat (POKIMAS) berbasis Vertikultur merupakan pendekatan yang memungkinkan untuk menjawab permasalahan tersebut.

\section{METODE PELAKSANAAN}

Situasi dan kondisi masa Pandemi Covid 19 membuat perombakan metode pelaksanaan POKIMAS. Koordinasi, komuniasi, serta pelatihan dilakukan secara daring dan modul edukasi diberikan secara lengkap dalam bentuk video dan link YouTube kepada semua sasaran sehingga mudah dipelajari mandiri di rumah. Tim PKM memberikan TOT (Training of Trainer) secara daring kepada tim inti BGBJ dan selanjutnya tim Inti tersebut bertanggung jawab memberikan pelatihan ke 10 peserta sasaran untuk melaksanakan POKIMAS secara langsung.

\section{HASIL DAN PEMBAHASAN}

\section{Karakteristik sasaran}

Kegiatan POKIMAS diawali dengan pengumpulan data baseline tentang kondisi sosial-ekonomi, pemenuhan pangan, serta kebiasaan makan sayur dan buah masyarakat sekitar Bantar Gebang. Kegiatan ini berhasil mendata 16 peserta rumah tangga yang merupakan ibu-ibu komunitas BGBJ, Bantar Gebang. Proporsi kepala rumah tangga berusia $<35$ tahun sebesar $50 \%$ dan $\geq 35$ tahun sebesar $50 \%$. Lebih dari $50 \%$ proporsi ibu rumah tangga berusia $\geq 30$ tahun. Usia sasaran masih termasuk usia produktif, dengan mata pencaharian seluruh kepala rumah tangga adalah sebagai pemulung.

Tabel 1. Karakteristik rumah tangga dan anak-anak

\begin{tabular}{|c|c|c|c|c|c|}
\hline Karakteristik rumah tangga & $\mathbf{n}$ & $\%$ & Karakteristik anak-anak & $\mathbf{n}$ & $\%$ \\
\hline Usia kepala keluarga & & & Usia & & \\
\hline$<35$ tahun & 8 & 50,0 & $<5$ tahun & 0 & 0,0 \\
\hline$\geq 35$ tahun & 8 & 50,0 & $\geq 5$ tahun & 11 & 100,0 \\
\hline Usia istri & & & Jenis kelamin & & \\
\hline$<30$ tahun & 7 & 43,8 & Laki-laki & 5 & 45,5 \\
\hline$\geq 30$ tahun & 9 & 56,3 & Perempuan & 6 & 54,5 \\
\hline Jumlah anggota keluarga & & & Status Gizi (IMT/U) & & \\
\hline$<4$ orang/keluarga & 6 & 37,5 & Gizi buruk & 0 & 0,0 \\
\hline$\geq 4$ orang/keluarga & 10 & 62,5 & Gizi kurang & 2 & 18,1 \\
\hline Pekerjaan kepala keluarga & & & Gizi baik & 4 & 36,4 \\
\hline
\end{tabular}




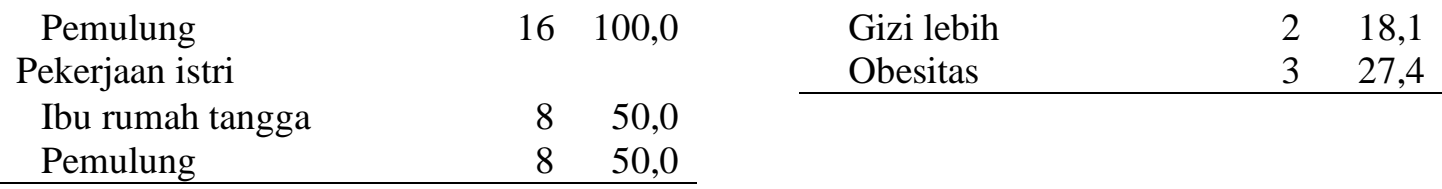

Usia anak-anak sasaran sudah seluruhnya di atas 5 tahun dengan perbandingan jumlah perempuan lebih banyak dibandingkan jenis kelamin laki-laki. Anak-anak sasaran program umumnya berstatus gizi baik ( 40\%), terdapat 2 orang anak bergizi kurang dan 3 orang yang obesitas.

\section{Kondisi pemenuhan pangan}

Pemenuhan pangan pada rumah tangga sasaran keseluruhan berasal dari membeli di luar rumah tangga, tidak ada yang mengambil dari kebun rumah/pekarangan, karena umumnya sasaran tidak memiliki halaman yang memadai untuk berkebun. Pengeluaran pangan sebagian besar rumah tangga umumnya lebih dari Rp. 50.000,per hari, hanya sebagian kecil ( 30\%) yang di bawah Rp. 50.000,- per hari. Hampir keseluruhan $(\sim 80 \%)$ rumah tangga tidak memiliki anggota yang berkebun di rumah.

Tabel 2. Kondisi pemenuhan pangan rumah tangga

\begin{tabular}{|c|c|c|}
\hline Kondisi pemenuhan pangan & $\mathbf{n}$ & $\%$ \\
\hline \multicolumn{3}{|l|}{ Asal makanan di rumah tangga } \\
\hline Membeli & 16 & 100,0 \\
\hline Mendapatkan dari tetangga lain & 0 & 0,0 \\
\hline Mengambil dari kebun rumah & 0 & 0,0 \\
\hline \multicolumn{3}{|l|}{ Pengeluaran pangan jika membeli } \\
\hline$<\operatorname{Rp} 50.000$ & 5 & 31,3 \\
\hline$\geq \operatorname{Rp} 50.000$ & 11 & 68,8 \\
\hline \multicolumn{3}{|c|}{ Keberadaan anggota rumah tangga (ART) berkebun rumahan } \\
\hline Ya & 3 & 18,8 \\
\hline Tidak & 13 & 81,3 \\
\hline \multicolumn{3}{|c|}{$\begin{array}{l}\text { Keberadaan ART yang menganggap berkebun rumahan dapat } \\
\text { memasok kebutuhan makanan keluarga }\end{array}$} \\
\hline Ya & 14 & 87,5 \\
\hline Tidak & 2 & 12,5 \\
\hline \multicolumn{3}{|l|}{ Fungsi utama kebun rumah saat ini, jika ada } \\
\hline Kebun sayur, tanaman obat, dan buah & 13 & 81,3 \\
\hline Kebun tanaman hias dan bunga & 3 & 18,8 \\
\hline Taman bermain & 0 & 0,0 \\
\hline Gudang penyimpanan & 0 & 0,0 \\
\hline \multicolumn{3}{|c|}{$\begin{array}{l}\text { Banyak makanan rumah tangga yang berasal dari pekarangan } \\
\text { rumah }\end{array}$} \\
\hline Hampir semua makanan & 0 & 0,0 \\
\hline Setengah dari makanan & 0 & 0,0 \\
\hline Kurang dari setengah dari makanan & 13 & 81,3 \\
\hline Tidak ada & 3 & 18,8 \\
\hline \multicolumn{3}{|l|}{ Makanan utama yang dibeli oleh rumah tangga } \\
\hline Beras & 16 & 100,0 \\
\hline Telur/Ikan/Daging & 14 & 87,5 \\
\hline Tahu/Tempe & 14 & 87,5 \\
\hline
\end{tabular}




\begin{tabular}{cccc}
\hline & Kondisi pemenuhan pangan & n & \% \\
\hline Sayur/Buah & 14 & 87,5 \\
\hline
\end{tabular}

Namun hampir keseluruhan ( $90 \%)$ anggota rumah tangga sasaran setuju bahwa berkebun di rumah dapat menyediakan kebutuhan makanan keluarga. Sebagian besar sasaran yang memiliki kebun di rumah umumnya menanam sayur, tanaman obat, dan buah sedangkan sebagian kecil lainnya hanya menanam tanaman hias dan bunga. Banyak makanan rumah tangga yang berasal dari pekarangan rumah kurang dari setengah dari seluruh yang dikonsumsi dalam rumah tangga. Dan umumnya yang dibeli secara berurut adalah beras, telur/ikan/daging, tahu/tempe, dan sayur/buah.

\section{Kondisi makan sayur dan buah}

Kebiasaan makan sayur dan buah sasaran program cenderung sering hal tersebut terlihat dari Tabel 3. Umumnya sayur yang sering dikonsumsi di rumah tangga sasaran adalah sayur sop dan bayam bening sedangkan buah yang sering dikonsumsi adalah pepaya dan lainnya.

Tabel 3. Kebiasaan makan sayur-buah rumah tangga dan anak-anak

\begin{tabular}{lrr}
\hline Kebiasaan Rumah Tangga & $\mathrm{n}$ & $\%$ \\
\hline Sayur favorit & & \\
$\quad$ Sayur sop & 8 & 50,0 \\
Tumis kangkung & 3 & 18,8 \\
$\quad$ Sayur bayam bening & 5 & 31,3 \\
$\quad$ Sayur caisim & 0 & 0,0 \\
Buah favorit & & \\
$\quad$ Pepaya & 5 & 31,3 \\
Pisang & 1 & 6,3 \\
Semangka & 3 & 18,8 \\
$\quad$ Melon & 0 & 0,0 \\
$\quad$ Lainnya & 7 & 43,8 \\
Frekuensi sayur/minggu & & \\
$\quad<5 \mathrm{x}$ & 6 & 37,5 \\
$\quad$ 25 x & 10 & 62,5 \\
Frekuensi buah/minggu & & \\
$\quad<3 \mathrm{x}$ & 6 & 37,5 \\
$\geq 3 \mathrm{x}$ & 10 & 62,5 \\
\hline
\end{tabular}

\begin{tabular}{lrr}
\hline Kebiasaan anak-anak & $\mathrm{n}$ & $\%$ \\
\hline Frekuensi buah/minggu & & \\
$\quad<2 \mathrm{x}$ & 5 & 45,5 \\
$\quad \geq 2 \mathrm{x}$ & 6 & 54,5 \\
Porsi makan buah/hari & & \\
$\quad<1$ porsi & 3 & 27,3 \\
$\quad \geq 1$ porsi & 8 & 72,7 \\
Frekuensi sayur/minggu & & \\
$\quad<5 \mathrm{x}$ & 4 & 36,4 \\
$\geq 5 \mathrm{x}$ & 7 & 63,6 \\
Porsi makan sayur/hari & & \\
$\quad<1$ porsi & 11 & 100,0 \\
$\geq 1$ porsi & 0 & 0,0 \\
\hline
\end{tabular}

Frekuensi rumah tangga mengonsumsi sayur per minggu sebagian besar sudah lebih dari 5 kali sedangkan buah sudah lebih dari 3 kali. Hal ini sejalan dengan frekuensi makan sayur dan buah anak-anak sasaran yaitu lebih dari $2 \mathrm{kali} / \mathrm{minggu}$ untuk buah-buahan dan 5 kali per minggu untuk sayuran. Namun porsi makan sayur/hari masih tergolong sedikit pada anak-anak sasaran, seluruh anak-anak makan sayur kurang dari 1 porsi per hari walaupun makan buah lebih dari 1 porsi sehari. Umumnya anak-anak sasaran lebih menyukai buah dibandingkan sayur.

\section{Kegiatan POKIMAS}

Berdasarkan hasil gambaran kondisi masyarakat sasaran terlihat bahwa belum banyak yang membuat kebun vertikultur rumahan walaupun frekuensi konsumsi sayur dan buah sudah cukup sering namun porsinya cenderung rendah. Sehingga 
program ini cocok diperkenalkan kepada rumah tangga sasaran. Kegiatan POKIMAS di Komunitas Kerajaan BGBJ, Bantar Gebang, Bekasi, Jawa Barat telah dilaksanakan pada tahap pertama karena berbagai kendala keterbatasan pelaksanaan saat pandemi Covid 19. Koordinasi dan komunikasi internal tim pelaksana dan juga mitra secara intens biasa dilakukan melalui whatsapp group, zoom meeting dan juga telepon.

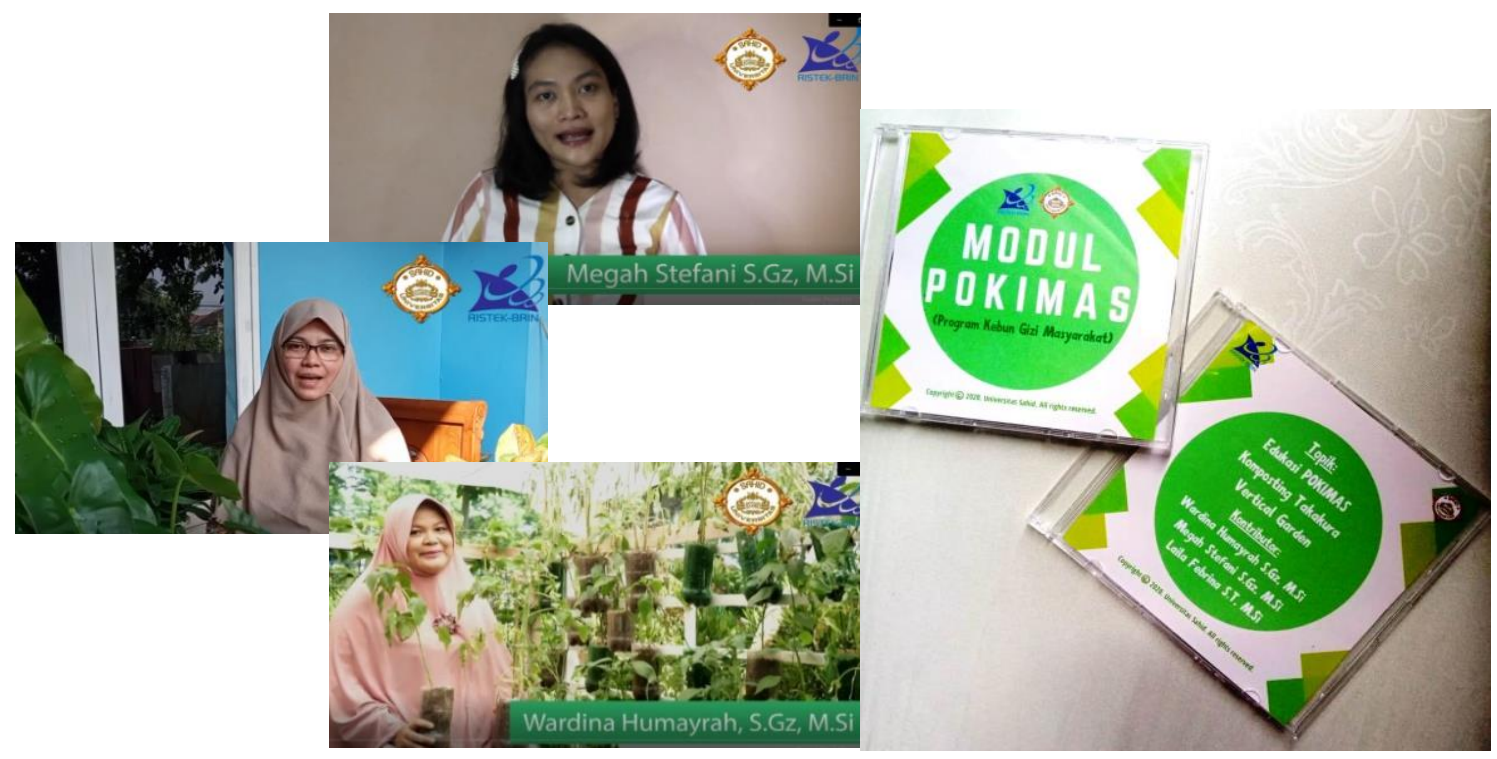

Pembahasan program tahap awal menghasilkan alur teknis pelaksanaan menyesuaikan kondisi pandemi dan pembuatan perangkat kuesioner untuk pengukuran keberhasilan program. Selain itu, hasil koordinasi awal ini berhasil menyepakati metode yang paling efisien untuk dilaksanakan secara daring yang dapat meminimalisir tatap muka namun dapat efektif berjalan. Tim pelaksana membuat 3 modul video terdiri dari rangkaian video-video singkat dan sederhana yang mudah dipahami masyarakat awam dalam bentuk Compact Disk (CD) dan link YouTube antara lain: edukasi POKIMAS perwujudan gizi seimbang, pembuatan pupuk takakura, dan pembuatan vertical garden rumahan.

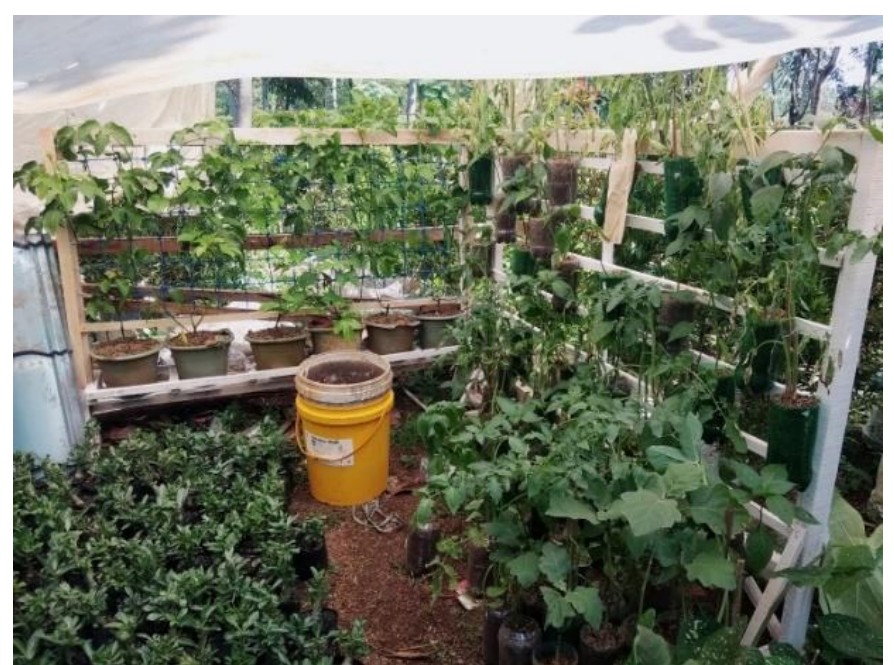

Gambar 2. Contoh tanaman vertikultur rumahan 
Selain itu, tim pelaksana juga menyediakan 3 unit vertikultur rumahan yang terdiri dari: 1 paket vertikultur untuk sayuran dengan ukuran 1 x 1,5 meter persegi, 1 paket vertikultur untuk cabai dan tomat ukuran 1 x 1,5 meter persegi, dan 1 paket vertikultur untuk buah markisa. Unit tanaman vertikultur tersebut merupakan percontohan untuk Tim BGBJ yang dapat dimanfaatkan masyarakat untuk acuan dalam pembuatan vertikultur di 10 rumah tangga sasaran program.

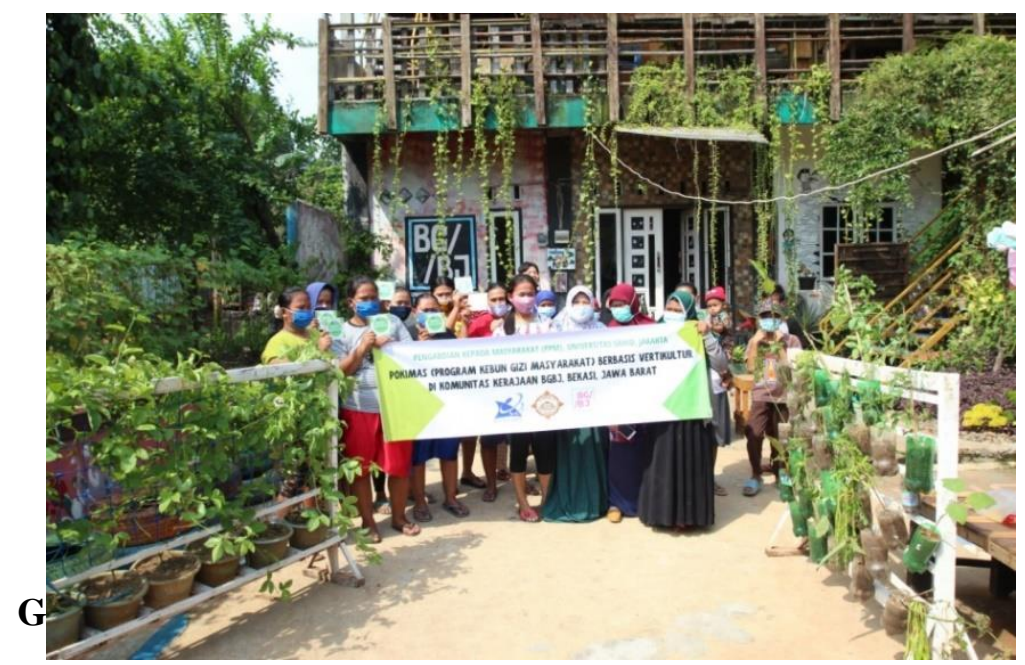

Training of Trainer (TOT) tim pelaksana kepada Tim BGBJ telah dilakukan secara daring untuk menyampaikan 3 topik utama dalam video modul, dan juga kesepakatan teknis untuk pelaksanaan TOT oleh Tim BGBJ kepada masyarakat sasaran. Tim Pelaksana juga telah melakukan Forum Group Discussion (FGD) kepada mitra dan masyarakat sasaran untuk melaksanakan kegiatan berkebun vertikultur. Kegiatan FGD ini terdiri dari pengisian informed consent keikutsertaan program, pembagian CD Modul Video, penyerahan 3 unit contoh tanaman vertikultur rumahan, serta rencana tindak lanjut kegiatan pelaksaan POKIMAS di 10 rumah tangga sasaran.

\section{KESIMPULAN}

Berdasarkan hasil data awal tentang masyarakat sasaran dapat disimpulkan bahwa sasaran membutuhkan program kebun rumah tangga yang sesuai dengan kondisi dan kemampuan yang mudah diterapkan. POKIMAS ini berpotensi untuk diterapkan pada masyarakat sasaran sekitar BGBJ, Bantar Gebang. Kegiatan pada tahap awal ini telah menghasilkan data-data baseline awal tentang kondisi sosio-ekonomi dan pemahaman awal masyarakat sasaran sekitar mitra tentang kebiasaan makan sayur dan buah; 3 modul terdiri dari rangkaian video-video singkat dan sederhana dalam bentuk Compact Disk (CD) dan link YouTube antara lain: edukasi POKIMAS perwujudan gizi seimbang, pembuatan pupuk takakura, dan pembuatan vertical garden rumahan serta kesepakatan jadwal dan kesepahaman untuk tindak lanjut pelaksanaan kegiatan POKIMAS di 10 rumah tangga sasaran. 


\section{DAFTAR PUSTAKA}

Boenard Resa. (2019). Seputar Kerajaan BGBJ. Wawancara langsung 12 Agustus 2019, Komunitas Kerajaan BGBJ, Bantar Gebang, Bekasi, Jawa Barat

Kurniasih Dwi Endah, Joko Adianto. 2018. Kebun gizi sebagai strategi berbasis masyarakat untuk memenuhi kebutuhan konsumsi. BKM Journal of Community Medicine and Public Health, Volume 34 No.2, Halaman 93-97

Kurniasih Dwi Endah, Kusumaningsih, R. (2014). Pemanfaatan Lahan sebagai Pendukung Program Pemenuhan Gizi Masyarakat Laporan Kajian Best Practice Kebun Gizi Mandiri Pemenang MDGs Award 2013 Dusun Karet Pleret Bantul Yogyakarta. Bandung: Cita Sehat Foundation Vol 1.

Mohammad A, Madanijah S. (2015). Konsumsi buah dan sayur anak usia sekolah dasar di Bogor. Jurnal Gizi dan Pangan, Volume 10: (1).

Mulyadi Didi. (2016). Mengembangkan kepedulian akan pentingnya pendidikan untuk meningkatkan kesejahteraan masyarakat pemulung di tpa bantar gebang. Prosiding Seminar Nasional dan Gelar Produk UMM, tanggal 17-18 Oktober 2016.

Pamungkas Hanggoro Sabdo, Retno Bandriyanti AP, Endang Setia M. (2013). Budidaya selada pada vertikultur hidroponik sistem karpet lettuce cultivation on hydroponic verticulture of carpet system. Agrosains 15(2): 41-45.

Satrio, Syafalni dan Paston Sidauruk. (2014). Studi Karakteristik Air Tanah Dangkal Sekitar TPST Bantar Gebang, Bekasi, dengan Metode Sumur Tunggal dan Ganda, Jurnal Ilmiah Aplikasi Isotop dan Radiasi, 10(1), 1 - 10.

Sitio Raston. (2017). Pengaruh Jumlah Sampah Masuk Bantargebang terhadap Biaya Kesehatan Masyarakat Ciketingudik dan Sumurbatu. Jurnal Aplikasi Manajemen, Ekonomi dan Bisnis, Vol. 2 (1), Oktober 2017, ISSN 25411438; E-ISSN 2550-0783, diterbitkan oleh STIM Lasharan Jaya. 